\title{
Producing Human Therapeutic Proteins in Plastids
}

\author{
J.M. Nugent* and S.M. Joyce
}

Institute of Bioengineering \& Agroecology, Biology Department, National University of Ireland Maynooth, Maynooth, Co. Kildare, Ireland

\begin{abstract}
Plastid transformation technology is set to become a major player in the production of human therapeutic proteins. Protein expression levels that can be achieved in plant plastids are hundreds of times greater than the expression levels generally obtained via nuclear transformation. Plastids can produce human proteins that are properly folded and are biologically active. Effective protein purification strategies and strategies that can achieve inducible plastid gene expression are being developed within the system. Plastid transformation technology has been extended to edible plant species, which could minimize down-stream processing costs and raises the possibility of "edible protein therapies". The system is limited by the fact that plastid-produced proteins are not glycosylated and that, at the moment, it can be difficult to predict protein stability within the plastid. The high level of protein expression that can be obtained in plastids could make it possible to produce high-value therapeutic proteins in plants on a scale that could be accommodated in contained glasshouse facilities and still be economically viable. Growing plastid-transformed plants under contained conditions, and coupled with the level of bio-safety conferred by maternal inheritance of plastid transgenes, would address many of the social and environmental concerns relating to plant based production of human therapeutic proteins.
\end{abstract}

Key Words: Transformation, plastid, plants, human, therapeutic, protein.

\section{INTRODUCTION}

Plant biotechnology has revolutionized the concept of plants both as traditional production systems and as production systems for novel proteins. Initial efforts of plant biotechnologists focused on using plant transformation to address the more conventional concerns of crop scientists and were mainly directed towards increasing crop yield (e.g. engineered insect or herbicide resistance $[1,2]$ ) or extending post-harvest shelf life [3,4]. More recent applications of plant biotechnology have focused on developing plants as bioreactors for the production of novel proteins with potential biomedical applications, including sub-unit vaccines, antibodies, and a range of other therapeutic compounds. This shift in emphasis was prompted by the need to produce therapeutic molecules free from human or animal pathogens, by a realization of the economy of scale offered by plant production systems relative to more conventional recombinant protein production systems, and by the need to demonstrate to a skeptical public that plant biotechnology has more to offer than genetically modified (GM) food destined for the supermarket shelf. The aim of this article is to review plant based production of human therapeutic proteins concentrating specifically on the plant plastid as a production system. The range of plant-produced products discussed in this article does not include sub-unit vaccines, secretory antibodies, or monoclonal antibodies, these products have been specifically dealt with either in a recent review or in other articles included in this issue [5-7].

It's nearly 20 years since the first human protein (human growth hormone) was expressed in plants [8]. The number of

\footnotetext{
*Address correspondence to this author at the Institute of Bioengineering \& Agroecology, Biology Department, National University of Ireland Maynooth, Maynooth, Co. Kildare, Ireland; Tel: +353 1708 3857; Fax: +3531708 6370; E-mail: jnugent@may.ie
}

human therapeutic proteins that have been expressed in plants via nuclear transformation has grown considerably since then (Table 1). These studies have demonstrated important points of principle relating to protein expression levels $[12,14,17,28,36,37]$, protein processing [9, 24, 27, $35]$, protein complex assembly [29, 43], protein glycosylation [13] and protein stability $[19,22,39,41]$ that are achievable in plant based systems. Clearly plant based expression systems have been shown to work, many times over. However, even after almost 20 years in development, human therapeutic protein production in plants can hardly be viewed as competing in a significant way with microbial systems. Indeed, very few recombinant proteins of any type have been produced in plants on a commercial scale (avidin, $\beta$-glucuronidase, trypsin) $[45,46,36]$.

Several factors have contributed to the delay in exploiting the potential of plants as expression systems for producing therapeutic proteins. One major factor is the low level of protein expression that is generally obtained with genes that are targeted to the nucleus. Typical protein expression levels have been well below the $1 \%$ total soluble protein (TSP) levels that have been used to compute the impressive cost estimates proposed for the production of plant based proteins [47]. This is not to imply that expression levels cannot be increased to levels that are economically viable. Several strategies have been adopted to increase recombinant protein production levels including the use of strong inducible or seed specific promoters as well as subcellular targeting of recombinant proteins [48]. Another successful strategy has been to backcross selected lines with elite germplasms bred to maximize agronomic characteristics $[36,45]$.

A second key factor that has hindered the adoption of plant based expression systems, particularly in Europe, relates to the "Catch 22" that is presented when large field- 
Table 1. Human Therapeutic Proteins Expressed in the Plant Nucleus

\begin{tabular}{|c|c|c|c|c|c|c|}
\hline Protein & $\begin{array}{c}\text { Glycosylation } \\
\text { state }\end{array}$ & Host plant & $\begin{array}{l}\text { Targeted } \\
\text { genome }\end{array}$ & Therapy & $\begin{array}{l}\text { Expression } \\
\text { levels }^{\mathrm{a}}\end{array}$ & $\operatorname{Refs}^{\mathbf{b}}$ \\
\hline \multicolumn{7}{|l|}{ Hormones: } \\
\hline Human growth hormone & NG & Tobacco & Nuclear & Hypopituitary dwarfism & $0.16 \% \mathrm{TSP}$ & [9] \\
\hline Calcitonin & NG & Potato & Nuclear & Osteoporosis & $0.02 \% \mathrm{TSP}$ & {$[10]$} \\
\hline Enkephalins & NG & $\begin{array}{c}\text { Arabidopsis } \\
\text { Oilseed }\end{array}$ & Nuclear & Antihyperanalgesic & $0.1 \%$ seed $\mathrm{P}$ & {$[11]$} \\
\hline \multicolumn{7}{|l|}{ Growth factors: } \\
\hline Epidermal growth factor & G & Tobacco & Nuclear & Wound repair & $0.11 \%$ TSP & {$[12]$} \\
\hline Human intrinsic factor & G & Arabidopsis & Nuclear & Pernicious Anaemia & $70 \mathrm{mg} / \mathrm{kg}$ WW & {$[13]$} \\
\hline $\begin{array}{l}\text { Human insulin-like growth } \\
\text { factor (IGF-1) }\end{array}$ & NG & $\begin{array}{l}\text { Tobacco } \\
\text { Rice }\end{array}$ & Nuclear & $\begin{array}{c}\text { Diabetes } \\
\text { Osteoporosis }\end{array}$ & $0.037 \% \mathrm{TP}$ & {$[14]$} \\
\hline Erythropoietin & G & Tobacco & Nuclear & Anaemia & $<0.01 \% \mathrm{TSP}$ & {$[15]$} \\
\hline \multicolumn{7}{|l|}{ Cytokines: } \\
\hline Interleukin-2,-10,-12,-13,-18 & NG & $\begin{array}{c}\text { Potato } \\
\text { Tobacco }\end{array}$ & Nuclear & Inflammation & $0.05 \% \mathrm{TSP}$ & [16-20] \\
\hline Tumour necrosis factor $\alpha$ & G & Potato & Nuclear & Anticoagulant & $15 \mu \mathrm{g} / \mathrm{g}$ FW & {$[21]$} \\
\hline $\begin{array}{l}\text { Granulocyte-macrophage } \\
\text { colony-stimulating factor }\end{array}$ & $\mathrm{G}$ & $\begin{array}{l}\text { Tobacco } \\
\text { Rice }\end{array}$ & Nuclear & $\begin{array}{c}\text { Neutropenia } \\
\text { Aplastic anemia }\end{array}$ & $0.03 \% \mathrm{TSP}$ & $\begin{array}{l}{[22]} \\
{[23]}\end{array}$ \\
\hline Interferon $\alpha$ & G & Potato & Nuclear & Antiviral agent & 3029U/g FW & {$[24]$} \\
\hline Interferon $\beta$ & G & Tobacco & Nuclear & Antiviral agent & $<0.01 \% \mathrm{FW}$ & {$[15,25]$} \\
\hline Interferon $\gamma$ & $\mathrm{NG} / \mathrm{G}$ & Tobacco & Nuclear & $\begin{array}{c}\text { Rheumatoid arthritis } \\
\text { Antiviral agent }\end{array}$ & $0.001 \% \mathrm{TSP}$ & {$[26]$} \\
\hline \multicolumn{7}{|l|}{ Blood proteins: } \\
\hline Serum albumin & NG & $\begin{array}{c}\text { Tobacco } \\
\text { Potato }\end{array}$ & Nuclear & $\begin{array}{l}\text { Liver cirrhosis } \\
\text { Burns }\end{array}$ & $0.2 \% \mathrm{TSP}$ & $\begin{array}{l}{[27]} \\
{[28]}\end{array}$ \\
\hline Hemoglobin $\alpha, \beta$ & $\mathrm{NG} / \mathrm{G}$ & Tobacco & Nuclear & Blood substitute & $0.05 \% \mathrm{TP}$ & {$[29]$} \\
\hline Hirudin & NG & Canola & Nuclear & Anticoagulant & $13000 \mathrm{U} / \mathrm{mg}$ & {$[30]$} \\
\hline Protein $\mathrm{C}$ & G & Tobacco & Nuclear & Anticoagulant & $<0.01 \% \mathrm{TSP}$ & {$[15,31]$} \\
\hline$\alpha 1$-antitrypsin & G & Rice & Nuclear & $\begin{array}{c}\text { Emphysema } \\
\text { Cystic fibrosis }\end{array}$ & $3.2 \mathrm{mg} / \mathrm{g} \mathrm{DW}$ & {$[32]$} \\
\hline \multicolumn{7}{|l|}{ Protein/peptide inhibitors: } \\
\hline Aprotinin & NG & Maize & Nuclear & Trypsin inhibitor & $0.069 \%$ seed SP & {$[33]$} \\
\hline Angiotensin-converting enzyme & G & $\begin{array}{l}\text { Tobacco } \\
\text { Tomato }\end{array}$ & Nuclear & Hypertension & not reported & {$[34]$} \\
\hline$\alpha$-trichosanthin & NG & Tobacco & Nuclear & HIV therapy & $2.7 \% \mathrm{TSP}$ & {$[35]$} \\
\hline \multicolumn{7}{|l|}{ Enzymes: } \\
\hline Trypsin & NG & Maize & Nuclear & Digestive insufficiency & $3.3 \% \mathrm{TSP}$ & {$[36]$} \\
\hline Glutamic acid decarboxylase 65 & NG & Tobacco & Nuclear & Type 1 Diabetes & $0.19 \%$ TSP & {$[37]$} \\
\hline Glucocerebrosidase & G & Tobacco & Nuclear & Gaucher disease & $0.001 \% \mathrm{TSP}$ & {$[38]$} \\
\hline
\end{tabular}


(Table 1) contd....

\begin{tabular}{|c|c|c|c|c|c|c|}
\hline Protein & $\begin{array}{c}\text { Glycosylation } \\
\text { state }\end{array}$ & Host plant & $\begin{array}{c}\text { Targeted } \\
\text { genome }\end{array}$ & Therapy & $\begin{array}{c}\text { Expression } \\
\text { levels }^{\mathrm{a}}\end{array}$ & Refs $^{b}$ \\
\hline Acetylcholinesterase & $\mathrm{NG} / \mathrm{G}$ & Tomato & Nuclear & $\begin{array}{c}\text { Organophosphate } \\
\text { poisoning }\end{array}$ & $\begin{array}{l}\text { 250nmolmin } \\
{ }^{1} \text { mgprotein }^{-1}\end{array}$ & {$[39]$} \\
\hline Human-secreted alkaline phosphatase & $\mathrm{G}$ & Tobacco & Nuclear & Hypophosphatasia & $3.0 \% \mathrm{TSP}$ & {$[40]$} \\
\hline Gastric lipase & G & Tobacco & Nuclear & Pancreatic insufficiency & $7 \%$ AEP & {$[41]$} \\
\hline Adenosine deaminase & $\mathrm{G}$ & Maize & Nuclear & Immuno-deficiency disorder & not reported & {$[42]$} \\
\hline \multicolumn{7}{|l|}{ Biopolymers: } \\
\hline Collagen & G & Tobacco & Nuclear & Tissue reconstruction & $30 \mathrm{mg} / \mathrm{kg}$ & {$[43]$} \\
\hline Elastin & NG & $\begin{array}{c}\text { Potato } \\
\text { Tobacco }\end{array}$ & Nuclear & Tissue reconstruction & $80 \mathrm{mg} / \mathrm{kg}$ & [44] \\
\hline
\end{tabular}

${ }^{\mathrm{a}}$ Only the highest available expression levels for each protein or class of protein are given

${ }^{\mathrm{b}}$ In some cases only reviews that cite original citations are provided

scale production of recombinant proteins in plants is considered. One of the advantages offered by the technology is the potential for cheap and easy scale-up of plant based protein production in field-scale conditions, indeed it is the scale-up potential that makes the technology economically viable. Unfortunately it is the perceived human and environmental risks associated with field-scale production that is the main disadvantage of the technology. Perceived risks include the possible spread of transgenes by seed or pollen dispersal, the potential for generating super-weeds or super-pests, the possibility of food chain contamination and/or human allergen exposure, the possibility of toxicity to non-target organisms. Several strategies can be adopted to minimize these risks including physical isolation and several genetic containment strategies. Two recent reviews have discussed the risk aspects associated with producing recombinant proteins in plants and the strategies that might be employed to assess and minimize these risks $[49,50]$.

However, an alternative strategy that can address the issue of increasing levels of protein expression and can also achieve a certain level of genetic containment is to bypass the nucleus and instead target transgenes for expression in the plant plastid genome.

\section{PLANT PLASTIDS}

Plastids are one of the three genetic compartments found in plant cells (plastid, nucleus, mitochondrion). Like mitochondria, plastids are thought to have evolved from a bacterial progenitor (cyanobacterial-like) that entered into a symbiotic relationship with a proto-eukaryotic cell [51]. "Plastid" is a general term that in fact describes several organelle types that are derived from undifferentiated proplastids found in the dividing cells of plant meristems [52]. The complement of plastid types found in any plant is organ and cell dependent and includes chloroplasts (leaves), chromoplasts (fruits and flowers), leucoplasts (petals), amyloplasts (seeds and tubers), and elaioplasts (fat/oil storage organs). Since all plastid types share a common developmental origin all plastid types in a given plant species contain the same plastid genome. In general, plant plastid genomes can be mapped as a single circular molecule and plastid genomes typically range in size from 120 to 190$\mathrm{kb}$ depending on the plant species [53]. A major structural feature of plastid genomes is the presence of a large inverted repeat (IR) region that divides the molecule into two single copy regions (large and small single copy regions); sequence identity across the IR region is maintained by frequent interand intra-molecular recombination. The number of plastids per cell is also cell-type and cell-size dependent; leaf cells are thought to contain the greatest number of plastids (up to 100 chloroplasts/cell). Each chloroplast can contain up to 100 copies of the plastid genome, thus, plant cells, and leaf cells in particular, may contain up to 10,000 copies of its plastid genome. Plastid inheritance occurs in a nonMendelian fashion and typically in flowering plants the plastid is inherited through the maternal lineage and is not transmitted via pollen [54].

Thus, plastids offer several obvious advantages over the plant nucleus for transgene expression:

1. An active endogenous recombination system that allows for targeted integration of transgenes via homologous recombination. This eliminates concerns over position effects on endogenous and transgene-expression and ensures reproducible levels of transgene expression.

2. The high ploidy level of plastid genomes ensures massive gene amplification after integration leading to potentially high levels of recombinant protein accumulation.

3. The bacterial-like nature of plastids allows for multiple transgenes to be stacked into operon-like expression casettes that are recognised by the plastid transcriptional and translational machinery.

4. Maternal inheritance eliminates the risk of genetic pollution via the spread of pollen from plastid transformed plants. 


\section{HUMAN THERAPEUTIC PROTEINS EXPRESSED IN PLASTIDS}

The range of human therapeutic proteins (non-vaccine, non-antibody) that have been expressed in plant plastids is still quite limited (Table 2). One of the major drawbacks of the plastid expression system is that plastids, like their bacterial relatives, have no capacity for protein glycosylation. Thus, proteins that require glycosylation before they can become biologically active are not suitable candidates for plastid based expression. However, those proteins that have been expressed in the plastid highlight the potential of the system from several perspectives: 1) the levels of protein expression that can be obtained; 2) the protein processing capacity of the plastid system; 3) the protein purification strategies that can be used to recover plastid produced proteins; 4) the potential for inducible gene expression in the plastid and 5) the potential for edible plastid-based protein therapies.

\section{Human Growth Hormone Somatotropin}

Human growth hormone somatotropin (hST) was one of the first recombinant human therapeutic proteins produced in bacteria [60] and also the first human protein to be expressed in plants [8]. Somatotropin is a small, non-glycosylated, protein that is secreted by the pituitary gland and requires the formation of two disulfide bonds for biological activity. The primary use of $\mathrm{hST}$ is to treat hypopituitary dwarfism in children but it may also have additional uses in the treatment of a range of other conditions including Turner syndrome, chronic renal failure, HIV wasting syndrome and age related physical decline in general [61]. hST has been expressed from the plant nucleus in a variety of contexts - as a nopaline synthase-hGT fusion protein [8], as a transit peptideprotein fusion that directs the protein to the chloroplast [55], as a protein targeted through the endoplasmic reticulum to the secretory pathway [55] and as a protein directed to accumulate in seeds [9]. The maximum level of protein accumulated from these nuclear constructs was $0.16 \%$ TSP [9]. In contrast, plastid based expression of hST in tobacco chloroplasts has achieved 10-300 times higher protein expression levels depending on the gene construction used [55]. The highest level of plastid-based hST protein expression (7\% TSP) was achieved using a chimeric ubiquitin-hGH gene construct under the control of the strong constitutive chloroplast ribosomal RNA operon promoter (Prrn) and containing a bacteriophage $\mathrm{T} 7$ gene 10 ribosome binding site [55]. Despite the fact that plastids have no apparent endogenous ubiquitin protease activity up to $80 \%$ of the total ubiquitin-hGH fusion protein produced was processed downstream of the ubiquitin C-terminal amino acid. The extent of protein processing was dependent on the protein extraction conditions used and presumably was carried out by non-plastid, plant ubiquitin proteases during the extraction process. In addition to proteolytic removal of the ubiquitin moiety most of the processed hGT protein

Table 2. Human Therapeutic Proteins Expressed in the Plastid

\begin{tabular}{|c|c|c|c|c|c|c|}
\hline Protein & $\begin{array}{c}\text { Glycosylation } \\
\text { state }\end{array}$ & Host plant & $\begin{array}{l}\text { Targeted } \\
\text { genome }\end{array}$ & Therapy & $\begin{array}{l}\text { Expression } \\
\text { levels }\end{array}$ & Refs \\
\hline \multicolumn{7}{|l|}{ Hormones: } \\
\hline Human growth hormone & NG & Tobacco & Chloroplast & $\begin{array}{c}\text { Hypopituitary dwarfism } \\
\text { Turner syndrome }\end{array}$ & $7.0 \% \mathrm{TSP}$ & {$[55]$} \\
\hline \multicolumn{7}{|l|}{ Cytokines: } \\
\hline Interferon $\gamma$ & $\mathrm{NG} / \mathrm{G}$ & Tobacco & Chloroplast & $\begin{array}{c}\text { Rheumatoid arthritis } \\
\text { Hepatitis B } \\
\text { Cancer }\end{array}$ & $6 \% \mathrm{TSP}$ & {$[26]$} \\
\hline \multicolumn{7}{|l|}{ Blood proteins: } \\
\hline Serum albumin & NG & Tobacco & Chloroplast & $\begin{array}{l}\text { Liver cirrhosis } \\
\text { Burns }\end{array}$ & $11.1 \% \mathrm{TSP}$ & {$[56]$} \\
\hline Hemoglobin $\alpha, \beta$ & NG & Tobacco & Chloroplast & $\begin{array}{l}\text { Blood substitute } \\
\text { Ischemia }\end{array}$ & - & [57] \\
\hline \multicolumn{7}{|l|}{ Biopolymers: } \\
\hline Elastin & NG & Tobacco & Chloroplast & Tissue reconstruction & not reported & {$[58]$} \\
\hline \multicolumn{7}{|l|}{ Antimicrobial peptides: } \\
\hline Magainins (MSI-99) & NG & Tobacco & Chloroplast & $\begin{array}{l}\text { Anti-cancer agent } \\
\text { Wound-healing }\end{array}$ & not reported & [59] \\
\hline
\end{tabular}


underwent an additional proteolytic cleavage that removed the N-terminal amino acid of the hGT protein. Removal of the N-terminal amino acid was obtained with either an Nterminal methionine or $\mathrm{N}$-terminal phenylalanine suggesting either that $\mathrm{N}$-terminal amino acid removal is an additional feature of the ubiquitin processing step or that removal was mediated by secondary aminopeptidase activity. Despite the fact that no known plastid-encoded proteins contain disulfide bonds the plastid produced properly folded hST that exhibited proper disulfide bond formation and was biologically active.

\section{Human Serum Albumin}

Human serum albumin (HSA) is the major protein component in blood serum and is used in the treatment of a wide range of medical conditions including large-scale plasma infusions for burn victims and patients who have lost large volumes of blood [62]. The demand for HSA is huge and typically more than $10 \mathrm{~g}$ of protein is required per administered dose. The annual world requirement for this blood protein (500 tons) is estimated to have a market value of more than $\$ 1.5$ billion [56]. HSA is a secreted preproprotein and proper folding of the protein requires the formation of 17 disulphide bonds. Commercial HSA is still obtained from human plasma despite the associated medical risks involved such as viral (HIV, hepatitis) and prion contamination. Recombinant HSA has been produced in a range of microbial expression systems, including $E$. coli [63], Saccharomyces cerevisiae [64] and Pichia pastoris [65] however, none of these systems has become commercially feasible mainly because the protein is susceptible to proteolytic degradation and is expensive to purify. Attempts to express HSA in the plant nuclear genome have achieved protein expression levels of up to $0.02 \%$ TSP in shoots and leaves (tobacco and potato) [27] and $0.2 \%$ TSP in potato tubers [28]. These expression levels are also not sufficient to make plant based nuclear expression of the protein a commercially viable option. Pharmaceutical industry estimates have suggested that plant based expression levels of at least $0.1 \mathrm{mg} \mathrm{HSA} / \mathrm{g}$ fresh weight are needed in order for the system to be considered cost-effective [28]. HSA expression and subsequent protein extraction from tobacco plastids, however, has surpassed these industry-required estimates for cost effective production. Expression of the mature HSA coding sequence under the control of the chloroplast, light regulated, psbA gene expression signals generated protein expression levels of between $7.2 \%$ and $11.1 \%$ TSP depending on the light conditions used to grow the transformed plants [56]. Plastid produced HSA accumulated in large inclusion bodies that significantly protected the protein from proteolysis and facilitated the purification of HSA from transformed plant tissue. Properly folded HSA was recovered from the plastids after solubilization of the inclusion bodies and subsequent in vitro protein refolding. Although the final amount of folded HSA recovered was only $20 \%$ of the initial amount of HSA produced in tobacco leaves, this represents a recovery of approximately $0.25 \mathrm{mg} \mathrm{HSA} / \mathrm{g}$ fresh weight, more than double the amount estimated by industry to be required for cost effective production.

\section{Human Interferon Gamma}

Although maximizing protein expression levels in plastids is important for the development of the system as a viable option for human therapeutic protein production, ultimately the success of the system will also depend on the development of efficient and cost effective protein purification strategies. Purifying recombinant proteins from plants is potentially more expensive compared to purification of the same product from microbial systems, mainly due to the low ratio of recombinant protein to total biomass of plant material $[15,34]$. Thus, strategies that minimise downstream processing costs will make plant-based expression systems more cost effective and economically viable.

Leelavathi and Reddy (2003) have developed an efficient strategy to both produce and purify recombinant human interferon gamma (IFN-g) from plant plastids [26]. IFN-g has been used in a wide range of human therapies, as an antiproliferative (treatment for several cancers), an immunoregulator (treatment for rheumatoid arthritis) and as an antiviral agent (treatment for hepatitis B virus infection). The human ifn $\mathrm{G}$ gene was transformed into the tobacco nuclear and plastid genomes and was initially expressed as an independent IFN-g protein [26]. The highest level of IFN$\mathrm{g}$ protein expression obtained from nuclear transformation was $0.001 \%$ TSP. The ifn $\mathrm{G}$ coding region was introduced into the tobacco plastid genome under the control of the rice psbA gene 5' and 3' expression signals. Expression of IFN-g from this construct in transplastomic tobacco plants was only $0.1 \%$ TSP (although still 100 fold higher than levels obtained with nuclear expression). A similar construct containing the reporter gene uidA (GUS), under the control of the same expression signals (rice $p s b \mathrm{~A}$ ), introduced into the tobacco plastid genome generated transformed plants with GUS expression levels 30 fold higher ( $3 \%$ TSP). Pulse labeling experiments indicated that the low level of IFN-g expression was due to significant proteolysis of the INF-g protein (halflife 4-6 hours) compared to GUS (half-life 48 hours). In order to boost INF-g expression levels a uidA:ifnG gene fusion, containing a HIS-tag at the 5'end of the uidA gene and a factor $\mathrm{Xa}$ recognition at the 5 ' end of the ifn $\mathrm{G}$ gene, was constructed and introduced into the tobacco plastid genome. Plants transformed with the fusion construct expressed GUS:IFN-g fusion protein to a level of 6\% TSP (60 fold higher than IFN-g alone). Pulse-labeling experiments indicated that the GUS:IFN-g had a half-life similar to GUS. The fusion protein was purified using HIStag based affinity chromatography and more than $75 \%$ of the total protein produced in tobacco leaves was subsequently recovered. The INF-g was cleaved from the purified GUS:IFN-g fusion by factor Xa digestion. The purified IFN$\mathrm{g}$ was bioactive and gave complete protection to human lung carcinomas (A549 cells) against EMC viral infection. Unlike the uncontrolled cleavage of hST from an ubiquitin-hST fusion protein that occurred during the protein extraction process $(30-80 \%$ cleavage efficiency depending on extraction method [55]) the GUS:IFN-g fusion protein remained intact until it was processed by factor Xa giving total control over the cleavage process. Theoretically this system, or a similar processing system, could be used to stabilize and purify any recombinant protein produced in the plant plastid. 


\section{Hemoglobin}

Demonstrating that plants have the potential to be used as efficient bioreactors to produce human therapeutic proteins is one issue. Actually translating this potential into fields of plants that are producing human drug therapies is quite another. One of the obvious potential dangers is the effect that pharmaceutical proteins could have on populations of soil microorganisms or insects and other animals that might feed on the plants [49]. One way to reduce the environmental risks posed by plant based pharmaceutical proteins is to restrict transgene expression, for example, to limit the expression of recombinant proteins to post-harvest tissue after the crop has been removed from field conditions. McBride et al (1994) first demonstrated controlled expression of plastid transgenes using a nuclear encoded, plastid-targeted, T7 RNA polymerase [66]. Magee et al. (2004) adopted this system in an attempt to develop an inducible plastid expression system for $\alpha$ - and $\beta$ - subunits of human adult hemoglobin [57].

Developing recombinant sources of human blood substitutes could significantly alleviate current concerns about conventional blood transfusion therapy. Recombinant hemoglobin has been produced in bacteria, yeasts, and in transgenic animals and plants [67, 29]. Co-expression of the $\alpha$ - and $\beta$ - chain of human hemoglobin in the nucleus of transgenic tobacco plants expressed functional tetrameric hemoglobin to levels of $0.05 \%$ TSP [29]. A di-cistronic expression cassette $(\mathrm{Hb})$ containing the human hemoglobin $\alpha$ - and $\beta$-subunit genes, under the transcriptional control of a phage $\mathrm{T} 7$ promoter, was introduced into the tobacco plastid genome [57]. Under normal conditions the plastid transcriptional machinery does not recognize this phage T7 promoter [66]. One of the plastid-transformed lines was crossed with a nuclear transformed line containing a salicylic acid-inducible plastid-targeted T7 RNA polymerase. Levels of $\mathrm{Hb}$ transcripts were assessed in detached leaves from progeny plants treated with $2 \mathrm{mM}$ salicylic acid solution or progeny plants directly sprayed with the salicylic acid solution. Although significant levels of $H b$ transcript were detected in untreated leaf tissue, transcript levels were higher in the salicylic acid treated leaves (both detached and attached leaves). However, despite high levels of $\mathrm{Hb}$ transcription no recombinant hemoglobin protein was detected in the dual plastid/nuclear transformed lines. Lack of protein expression is most likely due to protein instability in the plastid [57]. Modifying the gene construct and incorporating sequences that are known to enhance protein stability (5' UTR and N-terminal fusion sequences) could enhance hemoglobin protein expression levels in the plastid [68]. $H b$ transcription in the absence of induction was likely due to a basal level of the inducible promoter activity and the system could be improved by using alternative promoters that offer tighter control over gene expression. Several other chemically inducible systems are available in plants that could be more effective than the salicylic acid inducible promoter and could be used to regulate the expression of plastid transgenes [69]. Although this current system is not perfect, it clearly demonstrates the potential for inducible gene expression in plant plastids and the possibility for postharvest recombinant protein production in a plastid based expression system.

\section{Therapeutic Synthetic Peptides}

\section{Magainin-Like Peptides}

Magainins are short (20 to 26 amino acids) antimicrobial peptides (AMPs) that are found in plants and animals ranging from fruit flies to humans [70]. They constitute part of the innate defense system that curbs microbial flora and fights pathogen attack [71, 72]. These proteins are $\alpha$-helical peptide ionophores that rapidly dissipate ion gradients across membranes resulting in cell lysis. Magainins have been shown to lyse bacteria, hematopoietic tumor and solid target cells, viruses, fungi and sperm cells [71-73]. Magainins, and their analogues, have therapeutic potential as broad-spectrum topical agents, as anti-microbial agents to combat antibioticresistant "superbugs", as anti-cancer agents, and as a contraceptive with combined anti-viral, anti-bacterial and anti-fungal activity. The peptide MSI-99, an analogue of magainin 2 isolated from Xenopus laevis [74] was introduced into the tobacco plastid genome [59]. The transformed plants grew normally and showed no apparent morphological abnormalities. Although levels of MSI-99 protein expression were not directly assessed, the transplastomic plants exhibited significant in planta antifungal activity against the plant pathogens Pseudomonas syringae pv tabaci and Colletotrichum destructivum. In addition, leaf extracts from transplastomic plants significantly inhibited the growth of pre-germinated spores of three fungal species, Aspergillus flavus, Fusarium moniliforme and Verticillium dahliae [59].

Although these experiments demonstrate an obvious agricultural use for magainin-type AMPs, the fact that MSI99 can be expressed in tobacco plastids without any harmful effects on plants or plastids suggests that the system could also be used to express this class of peptide for human therapeutic use. One of the disadvantages of $\alpha$-helical AMPs is the instability of the proteins that makes them unsuitable for oral delivery [75]. However, plastid-based expression of unstable peptides in edible plant species could provide both a means of production and delivery of these peptides to the human gut. Both the plant cell wall and the plastid might offer a degree of controlled release of the peptide in the gut that could significantly enhance its therapeutic capability. A plastid transformation system is now available for tomato [76], a species that produces edible tissue that can be consumed without cooking. Tomato, and other plant species that can be consumed raw, would be excellent systems in which to develop plastid-based expression of AMPs and other therapeutic proteins that could be delivered orally as edible therapies.

\section{Elastin-Like Polymers}

Elastin is one of the strongest natural fibers commonly found in ligaments and arterial cell walls. Elastins are polymeric proteins composed of repeated sequences of basic amino acids usually Valine, Glycine and Proline. Bovine elastin has the sequence (Val-Pro-Gly-Val-Gly) ${ }_{11}$ without any amino acid deviation. Synthetic elastin-like polymers have been synthesized both chemically and by recombinant DNA technology for both medical and non-medical applications. The polymers have medical relevance because they are extremely biocompatible molecules that are ignored by the immune system and elicit no immune reaction. 
Elastin-like polymers are used for tissue reconstruction, to prevent post-surgical adhesions and scars, for drug delivery, as biosensors and as coatings for catheters and drainage tubes [77, 78, 79]. Non-medical applications are as transducers, thermoplastics with designable half-lives, food additives and cosmetics. A synthetic polymer gene (EG121), encoding the polymeric protein $(\mathrm{GVGVP})_{121}$ was engineered for expression in E.coli and generated extremely high levels of polymer protein production [80]. The EG121gene was subsequently introduced into both the tobacco nuclear and plastid genomes in the expectation that plants might generate polymer protein at a lower cost and at a higher volume than a microbial production system [81, 82, 58]. Surprisingly, despite the fact that polymer transcript levels were up to 100 fold higher in plastid transformants, the level of polymer protein expression was lower than in the highest expressing nuclear transformed line [58]. Since the synthetic polymer contains no known protease cleavage sites the low level of polymer protein expression in plastids is thought to be due to the unusual composition of the protein (40\% glycine, $40 \%$ valine and $20 \%$ proline) [58]. Although the amino acids valine and proline can be synthesized by plastids there is no plastid-based biosynthetic pathway for glycine and this amino acid has to be imported by the plastid. Thus, glycine availability could be a limiting factor for the low level of $(\mathrm{GVGVP})_{121}$ protein expression in plastids. In addition, availability of tRNAs could also be a contributing factor. The tobacco plastid genome encodes a set of 30 tRNA molecules that is sufficient to translate all 61 possible codons allowing for wobble base pairing in codon-anticodon recognition. However, the tobacco plastid genome has only a single gene that specifies tRNA-proline $(\operatorname{trn} P-U G G)$, thus, availability of tRNA-pro could be a limiting factor for plastid based production of this highly repetitive polymer protein [58]. Reducing the size of the polymeric protein could increase polymer protein expression levels in the plastid. Polymer size does not alter the useful properties of elastin-like proteins and most medical applications are carried out with much smaller molecules [83]. Attempts are being made to express a smaller synthetic polymer gene encoding the polymeric protein (GVGVP) 20 to see if this expresses better in the plant plastid [58].

\section{CONSIDERATIONS FOR PLASTID-BASED PROTEIN EXPRESSION}

\section{Host Species Options}

Until recently the only choice of host species for plastid transformation was the single-cell green alga Chlamydomonas reinhardtii or the land plant Nicotiana tabacum (tobacco). Although the Chlamydomonas plastid was the first plastid to be stably transformed [84], very little attention has been given to the development of this system for the production of recombinant proteins. This could be about to change and a recent review has discussed future prospects for recombinant protein production in Chlamydomonas [85]. By far the most popular plastid-based expression system in use is tobacco, and biolistic-mediated plastid transformation of tobacco is now routine in many labs [86]. Transplastomic tobacco plants can be generated quickly (primary transformed shoots can be regenerated in as little as three weeks) and at a relatively high frequency (one event per bombarded plate; [86]). A range of versatile vectors and expression cassettes are available that are capable of generating high levels of recombinant protein expression in tobacco plastids [87]. Tobacco can generate high yields of biomass, and since tobacco is a non-food crop for both humans and livestock, the risk of contaminating feed and human food chains with transgenic material is minimized. The disadvantage of the tobacco system is the high content of nicotine and other toxic alkaloids that have to be completely removed during protein purification steps and which add to downstream processing costs $[88,48]$.

After a slow start, plastid transformation is finally being extended to include a range of other plant species (Table 3). However, plastid transformation in these species is still considerably more laborious and time-consuming than in tobacco. Modifying tissue culture conditions and choice of cultivar could significantly improve transformation efficiency in these species. The availability of a plastid transformation system for tomato, a crop plant that can be eaten raw by humans, could reduce downstream processing costs and will now allow researchers to explore the possibility of edible, plastid-produced, drug therapies.

Table 3. Plant Species in Which Plastid Transformation has been Achieved

\begin{tabular}{|c|c|c|c|c|}
\hline Species & Transformation Method & Transformed genome state & Plant regeneration & Ref \\
\hline Tobacco & Biolistic, protoplast & Homoplasmic & Yes & {$[86,89]$} \\
\hline Potato & Biolistic & Homoplasmic & Yes & [90] \\
\hline Tomato & Biolistic & Homoplasmic & Yes & {$[76]$} \\
\hline Arabidopsis & Biolistic & Homoplasmic & Yes & [91] \\
\hline Lesquerella & Biolistic & Homoplasmic & Yes & [92] \\
\hline Oilseed rape & Biolistic & Heteroplasmic & Yes & [93] \\
\hline Rice & Biolistic & Heteroplasmic & Yes & [94] \\
\hline Soybean & Biolistic & Heteroplasmic & No & [95] \\
\hline
\end{tabular}




\section{Vector Design}

Plastid transformation vectors include plastid DNAtargeting regions that flank the expression cassette to be introduced into the plastid genome. Recombination between the vector target sequences and the homologous sequences on the plastid genome allows for directed integration of the transgene expression cassette. Transgenes have been introduced at up to 14 locations distributed throughout the plastid genome [87]. By far the most extensive set of transformation vectors have been designed for tobacco plastid transformation [87]. Some of the most commonly used tobacco vectors target both the large single copy region ( $\mathrm{pZS}$ range - $r b c \mathrm{~L}-a c c \mathrm{D}$; and $\mathrm{pRB}$ range - trn $\mathrm{M}-t r n \mathrm{G}$ ) and the inverted repeat region of the plastid genome (pPRV range $-\operatorname{trn} \mathrm{V}-r p s 12 / 7$ and $\mathrm{pLD}$ range-trn $\mathrm{I}-\operatorname{trn} \mathrm{A}$ ). There is no evidence that the choice of target site can affect protein expression levels, however, the choice of vector target sequences can sometimes affect plastid transformation frequency [76]. Vector target sequences have no special requirements, other than that they are homologous to the chosen target site, and generally include 1-2 kb of target DNA [68]. Tobacco vectors were used for plastid transformation in the related Solanceous species (potato and tomato) but the transformation frequency in these species was much lower than in tobacco. This suggests that chloroplast genomes can tolerate a certain level of mismatched recombination between homologous (though not identical) DNA sequences from closely related species. Plastid transformation in non-Solanaceous species have generally used vectors that are designed based on host genome target sites [91, 93-95].

\section{Expression Cassette Design}

Levels of recombinant protein produced in plastids is very much dependent on expression cassette design. Maliga
(2003) recently summarized the expression cassette constructs that have demonstrated high levels of protein expression in plastids [68]. Expression cassettes generally include a strong promoter to ensure high levels of transcription of the transgene and most cassettes use the strong plastid rRNA operon ( $r r n$ ) promoter. However, transcription is not the rate-limiting step in plastid gene expression. Rather, the level of protein expression in plastids is much more dependent on post-transcriptional processes such as transcript stability and translational initiation and elongation on polyribosomes $[68,96]$. The 5' and 3' untranslated regions (UTRs) from various sources of plastid genes have been incorporated into expression cassettes to stabilize transgene transcripts (3' UTRs) and to enhance translation initiation rates from these transcripts (5' UTRs) [68]. Post-translational processes can also significantly affect protein expression levels in the plastid. Some recombinant proteins are more susceptible to proteolysis in the plastid than others, and protein instability does not appear to be source dependent (human serum albumin is stable in plastids, human IFN-g and hemoglobin are not [56, 26, 57]). However, both heterologous protein fusions (ubiquitin and GUS) $[55,26]$ and fusions with the amino-termini of various source plastid proteins (RBCL and ATPB) can greatly enhance recombinant protein stability in plastids [68].

\section{THE FUTURE FOR PLASTID-BASED PRODUCTION OF HUMAN THERAPEUTIC PROTEINS}

Clearly, the plastid has huge potential for commercial scale production of human therapeutic proteins in plants and offers several advantages over a nuclear expression system (Table 4). The level of protein expression that can be obtained in plastids is $100 \mathrm{~s}$ of times higher than that generally obtained via the nucleus. Although the expression levels achieved for hST (7\% TSP), HSA (11.1\% TSP) and IFN-g (6\% TSP) have been very impressive they are still

Table 4. Comparison of Plant-Based Nuclear and Plastid Expression Systems

\begin{tabular}{|c|c|c|}
\hline & Nuclear expression & Plastid expression \\
\hline \hline Protein expression levels & Low/moderate & Possible \\
\hline Protein processing & Yes & Yes \\
\hline Disulfide bond formation & Yes & Possible \\
\hline Protein glycosylation & Yes & No \\
\hline Inducible gene expression & Yes & Polycistronic constructs \\
\hline Transgene silencing & Yes & Large \\
\hline Multiple transgene stacking & Genetic crossing high \\
\hline Scale up potential & Large & Limited \\
\hline Development time & High & Maternal (mostly) \\
\hline Species range & Most species & Medium \\
\hline Mode of inheritance & Mendelian & High \\
\hline Environmental concerns & & \\
\hline
\end{tabular}


considerably below the level of recombinant protein that has been obtained for the Bacillus thuringiensis cry2A crystal protein (45.3\% TSP) in plant plastids [97]. This suggests that levels of therapeutic protein expression in this system could still be significantly improved in the future, possibly by modifying gene regulatory and/or protein stabilizing sequences. Plastids can produce human proteins that are properly folded and are biologically active. Even proteins that require a significant number of disulphide bonds for proper folding are folded correctly in the plant plastid (HSA - 17 disulphide bonds; [56]). Both ubiquitin and factor $\mathrm{Xa}$ mediated processing of plastid-produced fusion proteins can generate mature proteins with non-methionine N-termini similar to many processed human proteins. The possibility of an inducible plastid gene expression system could lead to regulated plastid gene expression and might even allow for high levels of recombinant protein production in the plastids of post-harvest plant tissue. Plastid-based protein production in edible plant systems could minimize downstream protein processing costs and also raises the possibility of future "edible" protein therapies.

The disadvantages of the system are the lack of a glycosylation mechanism and the fact that, so far, there appear to be no hard and fast rules that can be applied to predict protein stability in the plastid. Pre-screening of plastid transgene expression cassettes in E.coli is not a reliable predictor of plastid expression levels [57]. Achieving maximum levels of human recombinant proteins in plastids still necessitates that transgenes are introduced into a range of cassettes that utilize different types of translational control. Thus, significant time and effort is still required to obtain the constructs that will generate a stable protein that can accumulate to high levels in the plastid. Protein stability was also a significant problem in the early days of bacterial expression systems and this was more or less solved by co-expressing chaperone proteins and reducing bacterial proteolytic capability. No doubt, general strategies to stabilize protein production can also be developed to increase the effectiveness of plastid expression systems in the future.

The number of human therapeutic proteins that have been expressed in plastids is still small. However, the system has obvious potential that could be applied to express a much wider range of therapeutic molecules. Several of the therapeutic proteins that have already been expressed in the plant nucleus (Table 1) could be good future targets for enhanced plastid-based expression. Proteins that have to be glycosylated before they become biologically active are not suitable candidates and plant-based expression of these proteins will continue to focus on the nucleus using various strategies to maximize protein expression levels. However, not all glycoproteins need to be glycosylated to be biologically active. For example, human IFN-g is glycosylated, semi-glycosylated and non-glycosylated in vivo [98] and non-glycosylated recombinant protein produced in $E$. coli and in the plastid is bioactive $[99,26]$. Human acetylcholinesterase is still enzymatic in the non-glycosylated state although glycosylation does appear to be important for enzyme stability [39]. Thus, glycosylation alone is not a good criterion by which to judge the suitability of a protein for plastid-based expression. Several of the human therapeutic proteins listed in Table $\mathbf{1}$ are not glycosylated in vivo and are more obvious potential targets for plastid-based expression. These potential targets include a broad range of therapeutic proteins including hormones (proinsulin), growth factors (insulin-like growth factor), blood proteins (hemoglobin, hirudin), cytokines (interleukins, tumor necrosis factor), enzymes (trypsin, glutamic acid decarboxylase) and no doubt many other proteins.

The jury is still out with respect to the future of large field-scale production of human therapeutic proteins in plants. Despite the obvious potential of plant-based protein expression systems their future relevance as bioreactors for biopharmaceutical proteins will ultimately depend on the level of containment (tissue, seed, pollen) that can be demonstrated within the system. Stringent regulatory guidelines and controls will have to be determined, and established, that address all aspects of consumer and environmental concerns before field-scale production of plant based human therapeutic proteins becomes a reality. The issues relating to field scale production will continue to be debated and are likely to become much more contentious if the levels of protein expression generally achieved in plants can make the technology significantly more economically viable than other production systems. Ultimately the choice of protein production system, plant $V$ non-plant or plant nucleus $V$ plant plastid, will depend on the balance achieved between protein market value, development costs, scale up potential and biosafety concerns. With respect to choosing between the two plant-based production systems (nucleus $V$ plastid), the high level of protein expression achievable in plastids could significantly reduce the level of scale-up required to make plant based protein production commercially feasible. Depending on the market value of the protein, the level of protein expression that is achieved, and the efficiency of downstream processing steps, it could be possible to produce plastid-based therapeutic proteins on a scale that could be accommodated in contained glasshouse conditions and still be an economically viable option. Growing plastid-transformed plants under contained conditions and coupled with the level of biosafety conferred by maternal inheritance of plastid transgenes, would go a long way towards addressing many of the social and environmental concerns relating to plant based production of human therapeutic proteins.

\section{ACKNOWLEDGEMENTS}

SMJ is supported by a grant from the Health Research Board, Ireland to JMN. We thank two anonymous reviewers for their comments on the manuscript.

\section{REFERENCES}

References 100-102 are related articles recently published in Current Pharmaceutical Design.

[1] Vaeck M, Reynaerts A, Höfte H, Jansens S, De Beuckeleer M, Dean $\mathrm{C}$, et al. Transgenic plants protected from insect attack. Nature 1987; 328: 33-37.

[2] De Block M, Botterman J, Vanderwiele M, Dockx J, Thoen C, Gossele V, et al. Engineering herbicide resistance in plants by expression of a detoxifying enzyme. EMBO J 1987; 6: 2513-2518.

[3] Smith CJS, Watson CF, Ray J, Bird CR, Morris PC, Schuch W, et al. Antisense RNA inhibition of polygalacturonase gene expression in transgenic tomatoes. Nature 1988; 334: 724-726. 
[4] Sheehy RE, Kramer M, Hiatt WR. Reduction of polygalacturonase activity in tomato fruit by antisense RNA. PNAS 1988; 85: 88058809.

[5] Streatfield SJ, Howard JA. Plant-based vaccines. Int. J. Parasitol 2003; 33: 479-493.

[6] Wycoff KL. Secretory IgA antibodies from plants. Curr Pharm Design 2004 in this issue.

[7] Stoger E, Sack M, Nicholson L, Fischer R, Christou P. Recent progress in plantibody technology. Curr Pharm Design 2004 in this issue.

[8] Barta A, Sommergruber K, Thompson D, Hartmuth K, Matzke MA, Matzke AJM. The expression of a Nopaline synthase human growth hormone chimeric gene in transformed tobacco and sunflower callus tissue. Plant Mol Biol 1986; 6: 347-357.

[9] Leite A, Kemper EL, da Silva MJ, Luchessi AD, Siloto RMP, Bonaccorsi ED, et al. Expression of correctly processed human growth hormone in seeds of transgenic tobacco plants. Mol Breed 2000; 6: 47-53.

[10] Ofoghi H, Moazami N, Domonsky NN, Ivanov I. Cloning and expression of human calcitonin genes in transgenic potato plants. Biotechnol Lett 2000; 22: 611-615.

[11] Kusnadi AR, Nikolov ZL, Howard JA. Production of recombinant proteins in transgenic plants: practical considerations. Biotechnol Bioeng 1997; 56: 473-484.

[12] Wirth S, Calamante G, Mentaberry A, Bussmann L, Lattanzi M, Barañao L, et al. Expression of active human epidermal growth factor (hEGF) in tobacco plants by integrative and non-integrative systems. Mol Breed 2004; 13: 23-35.

[13] Fedosov SN, Laursen NB, Nexo E, Moestrup SK, Petersen TE, Jensen EO, et al. Human intrinsic factor expressed in the plant Arabidopsis thaliana. Eur J Biochem 2003; 270: 3362-3367.

[14] Panahi M, Alli Z, Cheng X, Belbaraka L, Belgoudi J, Sardana R, et al. Recombinant protein expression plasmids optimized for industrial E. coli fermentation and plant systems produced biologically active human insulin-like growth factor- 1 in transgenic rice and tobacco plants. Transgen Res 2004; PC1142: 1-15.

[15] Daniell H, Streatfield SJ, Wycoff, K. Medical molecular farming: production of antibodies, biopharmaceuticals and edible vaccines in plants. Trends Plant Sci 2001; 6: 219-226.

[16] Park Y, Cheong H. Expression and production of recombinant human Interleukin-2 in potato plants. Protein Expr Purif 2002; 25: 160-165.

[17] Menassa R, Nguyen V, Jevnikar A, Brandle J. A self-contained system for the field production of plant recombinant interleukin-10. Mol Breed 2001; 8: 177-185.

[18] Kwon TH, Seo JE, Kim J, Lee JH, Jang YS, Yang MS. Expression and secretion of the heterodimeric protein interleukin-12 in plant cell suspension culture. Biotechnol Bioeng 2003; 81: 870-875.

[19] Eisenmesser EZ, Kapust RB, Nawrocki JP, Mazzulla MJ, Pannell LK, Waugh DS, et al. Expression, purification, refolding and characterization of recombinant human interleukin-13: Utilization of intracellular processing. Protein Expr Purif 2000; 20: 186-195.

[20] Zhang B, Yang YH, Lin YM, Rao Q, Zheng GG, Wu KF. Expression and production of bioactive human interleukin-18 in transgenic tobacco plants. Biotechnol Lett 2003; 25: 1629-1635.

[21] Ohya K, Itchoda N, Ohashi K, Onuma M, Sugimoto C, Matsumura T. Expression of biologically active human tumour necrosis factor$\alpha$ in transgenic potato plant. J. Interferon Cytokine Res 2002; 22: 371-378.

[22] Sardana RK, Alli Z, Dudani A, Tackaberry E, Panahi M, Narayanan, M, et al. Biological activity of human granulocytemacrophage colony stimulating factor is maintained in a fusion with seed glutelin peptide. Transgen Res 2002; 11: 521-531.

[23] Shin YJ, Hong SY, Kwon TH, Jang YS, Yang MS. High level of expression of recombinant human granulocyte-macrophage colony stimulating factor in transgenic rice cell suspension culture. Biotechnol Bioeng 2003; 82: 778-783.

[24] Sawahel WA. The production of transgenic potato plants expressing human $\alpha$-interferon using lipofectin-mediated transformation. Cell. Mol Biol Lett 2002; 7: 19-29.

[25] Edelbaum O, Stein, D, Holland N, Gafni Y, Livneh O, Novick D, et al. Expression of active human interferon-beta in transgenic plants. J. Interferon Res 1992; 12: 449-453.
[26] Leelavathi S, Reddy VS. Chloroplast expression of His-tagged GUS-fusions: a general strategy to overproduce and purify foreign proteins using transplastomic plants as bioreactors. Mol Breed 2003; 11: 49-58.

[27] Sijmons PC, Dekker BM, Schrammeijer B, Verwoerd TC, van den Elzen PJ, et al. Production of correctly processed human serum albumin in transgenic plants. Biotechnol 1990; 8: 217-221.

[28] Farran I, Sanchez-Serrano JJ, Medina JF, Prieto J, Mingo-Castel AM. Targeted expression of human serum albumin to potato tubers. Transgen Res 2002; 11: 337-346.

[29] Dieryck W, Pagnier J, Poyart C, Marden MC, Gruber V, Bournat P, et al. Human haemoglobin from transgenic tobacco. Nature 1997, 386, 29-30.

[30] Boothe JG, Saponja JA, Parmenter DL. Molecular farming in Plants: Oilseeds as vehicles for the production of pharmaceutical proteins. Drug Dev Res 1997; 42: 172-181.

[31] Cramer CL, Boothe JG, Oishi KK. Transgenic plants for therapeutic proteins: linking upstream and downstream strategies. Curr Top MicroBiol Immunol 1999; 240: 95-118.

[32] Trexler MM, McDonald KA, Jackman AP. Bioreactor production of human $\alpha_{1}$-antitrypsin using metabolically regulated plant cell cultures. Biotechnol Prog 2002; 18: 501-508.

[33] Zhong GY, Peterson D, Delaney DE, Bailey M, Witcher DR, Register III, JC, et al. Commercial production of aprotinin in transgenic maize seeds. Mol Breed 1999; 5: 345-356.

[34] Giddings G, Allison G, Brooks D, Carter A. Transgenic plants as factories for biopharmaceuticals. Nature Biotech 2000; 18: 11511155 .

[35] Krishnan R, McDonald KA, Dandekar AM, Jackman AP, Falk B. Expression of recombinant trichosanthin, a ribosome-inactivating protein, in transgenic tobacco. J Biotechnol 2002; 97: 69-88.

[36] Woodard SL, Mayor JM, Bailey MR, Barker DK, Love RT, Lane $\mathrm{JR}$, et al. Maize (Zea mays)-derived bovine trypsin: characterization of the first large-scale, commercial protein product from transgenic plants. Biotechnol Appl Biochem 2003; 38: 123-130.

[37] Avesani L, Falorni A, Tornielli GB, Marusic C, Porceddu A, Polverari A, et al. Improved in planta expression of the human islet autoantigen glutamic acid decarboxylase (GAD65). Transgen Res 2003; 12: 203-212.

[38] Cramer CL, Weissenborn DL, Oishi KK, Grabau EA, Bennett S, Pon Grabowski GA, et al. Bioproduction of human enzymes in transgenic tobacco. Ann NY Acad Sci 1996, 792, 62-71.

[39] Mor TS, Sternfeld M, Soreq H, Arntzen CJ, Mason HS. Expression of recombinant human acetylcholinesterase in transgenic tomato plants. Biotechnol Bioeng 2001; 75: 259-266.

[40] Komarnytsky S, Borisjuk NV, Borisjuk LG, Alam MZ, Raskin I. Production of recombinant proteins in tobacco guttation fluid. Plant Physiol 2000; 124: 927-933.

[41] Gruber V, Berna PP, Arnaud T, Bournat P, Clément C, Mison D, et al. Large-scale production of a therapeutic protein in transgenic tobacco plants: effect of subcellular targeting on quality of a recombinant dog gastric lipase. Mol Breed 2001; 7: 329-340.

[42] Petolino JF, Young S, Hopkins N, Sukhapinda K, Woosley A, Hayes $\mathrm{C}$, et al. Expression of murine adenosine deaminase (ADA) in transgenic maize. Transgen Res 2000; 9: 1-9.

[43] Ruggiero F, Exposito JY, Bournat P, Gruber V, Perret S, Comte J, et al. Triple helix assembly and processing of human collagen produced in transgenic tobacco plants. FEBS Lett 2000; 469: 132136.

[44] Scheller J, Henggeler D, Viviani A, Conrad U. Purification of spider silk-elastin from transgenic plants and application for human chondrocyte proliferation. Transgen Res 2004; 13: 51-57.

[45] Hood EE, Witcher DR, Maddock S, Meyer T, Baszczynski C, Bailey $\mathrm{M}$, et al. Commercial production of avidin from transgenic maize: characterization of transformant, production, processing, extraction and purification. Mol Breed 1997; 3: 291-306.

[46] Witcher DR, Hood EE, Peterson D, Bailey M, Bond D, Kusnadi A, et al. Commercial production of $\beta$-glucuronidase (GUS): a model system for the production of proteins in plants. Mol Breed 1998; 4: 301-312.

[47] Hood EE, Woodard SL, Horn ME. Monoclonal antibody manufacturing in transgenic plants - myths and realities. Curr Opin Biotechnol 2002; 13: 630-635. 
[48] Fischer R, Stoger E, Schillberg S, Christou P, Twyman RM. Plantbased production of biopharmaceuticals. Curr Opin Plant Biol 2004; 7: 152-158.

[49] Mascia PN, Flavell RB. Safe and acceptable strategies for producing foreign molecules in plants. Curr Opin Plant Biol 2004; 7: 189-195.

[50] Peterson RKD, Arntzen CJ. On risk and plant-based biopharmaceuticals. Trends Biotechnol 2004; 2: 64-66.

[51] Gray MW. Evolution of organellar genomes. Curr Opin Genet. Dev 1999; 9: 678-687.

[52] Pyke KA. Plastid Division and Development. Plant Cell 1999; 11 : 549-556.

[53] Sugiura M, Hirose T, Sugita M. Evolution and mechanism of translation in chloroplasts. Annu Rev Genet 1998; 32: 437-459.

[54] Birky, CW. The inheritance of genes in mitochondria and chloroplasts: laws, mechanisms, and models. Annu Rev Genet 2001; 35: 125-148.

[55] Staub JM, Garcia B, Graves J, Hajdukiewicz PTJ, Hunter P, Nehra $\mathrm{N}$, et al. High-yield production of a human therapeutic protein in tobacco chloroplasts. Nature Biotech 2000; 18: 333-338.

[56] Fernández-San Millán A, Mingo-Castel A, Miller M, Daniell H. A chloroplast transgenic approach to hyper-express and purify human serum albumin, a protein highly susceptible to proteolytic degradation. Plant Biotechnol J 2003; 1: 71-79.

[57] Magee AM, Hovrath EM, Kavanagh TA. Pre-screening plastid transgene expression cassettes in Escherichia coli may be unreliable as a predictor of expression levels in chloroplasttransformed plants. Plant Sci 2004; 166: 1605-1611.

[58] Guda C, Lee SB, Daniell H. Stable expression of a biodegradable protein-based polymer in stable tobacco chloroplasts. Plant Cell Rep 2000; 19: 257-262.

[59] DeGray G, Rajasekaran K, Smith F, Sanford J, Daniell H. Expression of an Antimicrobial Peptide via the Chloroplast Genome to control Phytopathogenic Bacteria and Fungi. Plant Physiol 2001; 127: 852-862.

[60] Goeddel DV, Heyneker HL, Hozumi T, Arentzen R, Itakura K, Yansura DG, et al. Direct expression in Escherichia coli of a DNA sequence coding for human growth hormone. Nature 1979; 281: 544-548.

[61] Tritos NA, Mantzoros CS. Recombinant human growth hormone: old and novel uses. Am J Med 1998; 105: 44-57.

[62] Peters T. The Albumin molecule. In: All about Albumin: Biochemistry, Genetics and Medical Applications 1995; San Diego, CA, Academic Press.

[63] Latta L, Knapp M, Sarmientos P, Brefort G, Becquart J, Guerrier L, et al. Synthesis and purification of mature human serum albumin from Escherichia coli. Bio/Technol 1987, 5, 1309-1314.

[64] Quirk AV, Geisow MJ, Woodrow JR, Burton SJ, Wood PC, Sutton $\mathrm{AD}$, et al. Production of recombinant human serum albumin from Saccharomyces cerevisiae. Biotechnol Appl. Biochem 1989; 11: 273-287.

[65] Ohtani W, Ohda T, Sumi A, Kobayashi K, Ohmura T. Analysis of Pichia pastoris components in recombinant human serum albumin by immunological assays and by HPLC with pulsed amperometric detection. Anal. Chem 1998; 70: 425-429.

[66] McBride KE, Schaaf DJ, Daley M, Stalker DM. Controlled expression of plastid transgenes in plants based on a nuclear DNAencoded and plastid-targeted T7 RNA polymerase. PNAS 1994; 91: 7301-7305.

[67] Kumar R. Recombinant hemoglobins as blood substitutes: a biotechnology perspective. Proc Soc Exp Biol Med 1995; 208: 150158.

[68] Maliga P. Progress towards commercialization of plastid transformation technology. Trends Biotechnol 2003; 21: 20-28.

[69] Padidam M. Chemically regulated gene expression in plants. Curr Opin Plant Biol 2003; 6: 169-177.

[70] Berkowitz BA, Bevins CL, Zasloff MA. Magainins: a new family of membrane-active host defense peptides. Biochem Pharmacol 1990; 39: 625-629.

[71] Tossi A, Sandri L, Giangaspero A. Amphipathic, $\alpha$-helical antimicrobial peptides. Biopolymers 2000; 55: 4-30.
[72] Jacob L, Zasloff M. Potential therapeutic applications of magainins and other antimicrobial agents of animal origin. Ciba Found Symp 1994; 186: 197-216.

[73] Reddy VR, Manjramkar DD. Evaluation of the antifertility effect of magainin-A in rabbits: in vitro and in vivo studies. Fertil Steril 2000; 73: 353-358.

[74] Zaslof M. Magainins, a class of antimicrobial peptides from Xenopus skin: isolation, characterization of two active forms and partial cDNA sequence of a precursor. Proc Natl Acad Sci USA 1987; 84: 5449-5453.

[75] Epand RF, Umezawa N, Porter EA, Gellman SH, Epand RM. Interactions of the antimicrobial $\beta$-peptide $\beta-17$ with phospholipid vesicles differ from membrane interactions of magainins. Eur $\mathbf{J}$ Biochem 2003; 270: 1240-1248.

[76] Ruf S, Hermann M, Berger IJ, Carrer H, Bock R. Stable genetic transformation of tomato plastids and expression of a foreign protein in fruit. Nature Biotech 2001; 19: 870-875.

[77] Urry DW. Elastic biomolecular machines. Sci Amer 1995; 272: 6469.

[78] Urry DW, Nicol A, Gowda DC, Hoban LD, McKee A, Williams T, et al. Medical applications of bioelastic materials. In: Gebelain C.G. (ed.) Biotechnological polymers: medical, pharmaceutical and industrial applications. Technomic Publ. Co. Inc., Atlanta, Georgia 1993; 82:103.

[79] Urry DW, McPherson DT, Xu J, Daniell H, Guda C, Gowda DC, et al. Protein-based polymeric materials: syntheses and properties. In: The Polymeric Materials Encyclopedia: Synthesis, Properties and Applications. CRC Press, Boca Raton 1996; 7263-7279.

[80] Guda C, Zhang X, McPherson DT, Xu J, Cherry JH, Urry DW, et al. Hyperexpression of an environmentally friendly synthetic polymer gene. Biotechnol Lett 1995; 17: 745-750.

[81] Zhang X, Guda C, Datta R, Dute R, Urry DW, Daniell H. Nuclear expression of an environmentally friendly synthetic protein-based polymer gene in tobacco cells. Biotechnol Lett 1995; 17: 12791284.

[82] Zhang X, Urry DW. Expression of an environmentally friendly synthetic protein-based polymer gene in transgenic tobacco plants. Plant Cell Rep 1996; 16: 174-179.

[83] McPherson DT, Xu J, Urry DW. Product purification by reversible phase transition following Escherichia coli expression of genes encoding up to 251 repeats of the elastomeric pentapeptide GVGVP. Protein Expr Purif 1996; 7: 51-57.

[84] Boynton JE, Gillham NW, Harris EH, Hosler JP, Johnson AM, Jones AR, et al. Chloroplast transformation in Chlamydomonas with high velocity microprojectiles. Science 1988; 240: 1534-1538.

[85] Franklin SE, Mayfield SP. Prospects for molecular farming in the green alga Chlamydomonas reinhardtii. Curr Opin Plant Biol 2004; 7: 159-165.

[86] Svab Z, Maliga P. High-frequency plastid transformation in tobacco by selection for a chimeric aadA gene. PNAS 1993; 90 : 913-917.

[87] Maliga P. Plastid transformation in higher plants. Annu. Rev Plant Biol 2004; 55: 289-313.

[88] Stoger E, Vaquero C, Torres E, Sack M, Nicholson L, Drossard J, et al. Cereal crops as viable production and storage systems for pharmaceutical scFv antibodies. Plant Mol Biol 2000; 42: 583-590.

[89] Golds T, Maliga P, Koop HU. Stable plastid transformation in PEG-treated protoplasts of Nicotiana tabacum. Bio/Technol 1993; 11: $95-97$.

[90] Sidorov VA, Kasten D, Pang SZ, Hajdukiewicz PTJ, Staub JM, Nehra NS. Stable chloroplast transformation in potato: use of green fluorescent protein as a plastid marker. Plant J 1999; 19: 209-216.

[91] Sikdar SR, Serino G, Chaudhuri S, Maliga P. Plastid transformation in Arabidopsis thaliana. Plant Cell Rep 1998; 18: 20-24.

[92] Skarjinskaia M, Svab Z, Maliga P. Plastid transformation in Lesquerella fendleri, an oilseed Brassicacea. Transgen Res 2003; 12: $115-122$.

[93] Hou BK, Zhou YH, Wan LH, Zhang ZL, Shen GF, Chen ZH, et al. Chloroplast transformation in oilseed rape. Transgen Res 2003; 12: 111-114.

[94] Khan MS, Maliga P. Fluorescent antibiotic resistance marker for tracking plastid transformation in higher plants. Nature Biotechnol 1999; 17: 910-915. 
[95] Zhang XH, Portis AR Jr, Wildholm JM. Plastid transformation of soybean suspension cultures. J Plant Biotechnol 2001; 3: 39-44.

[96] Heifetz PB, Tuttle AM. Protein expression in plastids. Curr Opin Plant Biol 2001; 4: 157-161.

[97] DeCosa B, Moar W, Lee SB, Miller M, Daniell H. Overexpression of the Bt cry2Aa2 operon in chloroplasts leads to the formation of insecticidal crystals. Nature Biotechnol 2001; 19: 71-74.

[98] James DC, Freedman RB, Hoare M, Ogonah OW, Rooney BC, Larionov OA, et al. N-glycosylation of recombinant human interferon-gamma produced in different animal expression systems. Biotechnol 1995; 13: 592-596.
[99] Arora D, Khanna N. Method for increasing the yield of properly folded recombinant human gamma interferon from inclusion bodies. J Biotechnol 1996; 52: 127-133

[100] Kitts DD, Weiler K. Bioactive proteins and peptides from food sources. Applications of bioprocesses used in isolation and recovery. Curr Pharm Design 2003; 9(16): 1309-23.

[101] Korhonen H, Pihlanto A. Food-derived bioactive peptides-opportunities for designing future foods. Curr Pharm Design 2003; 9(16): 1297-308.

[102] Teschemacher $H$. Opioid receptor ligands derived from food proteins. Curr Pharm Design 2003; 9(16): 1331-44. 
Reproduced with permission of the copyright owner. Further reproduction prohibited without permission. 